https://doi.org/10.15407/econlaw.2021.04.094

UDC 332

D.O. GRICISHEN, Dr. Sci. in Economics, Dean of the Faculty of Public Administration and Law Zhytomyr Polytechnic State University, Zhytomyr, Ukraine

(iD) orcid.org/0000-0001-5484-6421

V.O. KUCHMENKO, PhD in Economics, Head of the Center for Postgraduate Education, Associate Professor of the Department of Economic Security, Public Administration and Administration Zhytomyr Polytechnic State University, Zhytomyr, Ukraine

(iD) orcid.org/0000-0001-5484-6421

D.V. ZABLODSKA, PhD in Economics, acting Researcher State Organization "V. Mamutov Institute of Economic and Legal Research of NAS of Ukraine", Kyiv, Ukraine (iD) orcid.org/0000-0002-5670-597X

\title{
ECONOMIC SECURITY OF THE REGION IN THE CONTEXT OF ITS POSITIONING
}

\begin{abstract}
Ключові слова: economic security of the region, positioning, indicators, directions, mechanism, functional components, synergistic effect.
\end{abstract}

The article summarizes scientific approaches to the economic security of the region in the context of its positioning. The key risks of economic security of the Ukrainian regions have been identified as well as the most important criteria for regions positioning: the gross regional product (GRP) structure, the volume and rates of industrial development, the volume and dynamics of investments; natural resource production and scientific and technical potential; resource efficiency; competitiveness of the region's economy; unemployment rate; the quality of life, the degree of income differentiation, the provision of the population with material benefits and services; energy dependence; integration into the national economy etc. It is noted that the main problem of economic security is to ensure effective management of regional policy, as well as the evaluation of the region positioning in the context of economic security can be carried out in the main directions: the level of poverty and unemployment in the region; the quality of life of the population; demographic component of the socio-economic security of the region; the ability of the region's economy to sustainably grow; stability of the region's financial system; support of the scientific potential of the region; dependence of the region's economy on imports of the most important types of products; relations of the region with the countries of the European Union. The modern positioning of some security sectors and the consequences of such positioning have been characterized. A system of main indicators has been formed that allows to quantify the level of economic security of the region in the context of its positioning. The methodical approach to evaluating the economic security of a region in the context of its positioning is highlighted. It is noted that despite the goals that are taken into account when positioning the region, the whole process can be structured into the following blocks: organizational and analytical support; methodical and informational support; conceptual software. The article presents the functional components of the mechanism for ensuring the economic security of regions in the context of their positioning. It has been proved that the effective functioning of the mechanism for ensuring the economic security of regions in the context of their positioning requires the effective functioning of all subjects synchronously, which made it possible to formulate a synergistic effect in a formalized form.

Ц и ту в ан н я: Gricishen D.O., Kuchmenko V.O., Zablodska D.V. Economic security of the region in the context of its positioning. Економіка та право. 2021, № 4. C. 94-100. https://doi.org/10.15407/econlaw.2021.04.094 
Problem statement and relevance of the research. The national level of economic security is determined by the level of security of regional systems, and the process of guaranteeing the economic security of the state should be implemented based on taking into account and complying with the security of territorial and administrative units. The reasons for threats to the economic security of the state have a regional aspect, so the study of the territorial aspect of economic security makes it possible to determine the key criteria for its positioning.

The modern development of the national economy actualizes scientific research on the problems of economic security of regions and their positioning because most threats have a pronounced regional character. The dependence of economic security of regions on some territorial, sectoral, geoeconomic aspects makes these studies an urgent problem for the scientific community.

Analysis of recent research and publications. The modern scientific literature offers different approaches to the study of economic security of regions, depending on the purpose and objectives of research. Indeed, the economic security of the region is a multifaceted, multidimensional object of scientific analysis, and the problems of its positioning are dealt with by various sciences - economics, engineering, management, law and many others.

Issues of economic security of the regions are constantly in the spotlight of scientists. The works of such domestic and foreign scientists as V.M. Geets, M.O. Kyzym, T.S. Klebanova, O.I. Chernyak, Z.V. Gerasymchuk, G.V. Gutman, Y.N. Lapygin, A.I. Prilepsky, V.O. Shurshin, R.R. Bilyk, O.V. Nosova, O.S. Makovoz, D.I. Povzun, L.M. Akimova, R.R. Bilyk, Z.V. Gbur, T.N. Agapova, O.A. Burbelo, T.V. Patriarch, S.O. Burbelo, V.N. Antonenko, G.A. Portnova, B.V. Burlutsky, V.V. Dykan, O.Y. Alexandrova and others [1-13] are devoted to the problems of economic security of the region. At the same time, the regional aspects of positioning the economic security of Ukraine are incompletely studied, they need further theoretical and applied consideration.

The article aims to generalize scientific approaches to the economic security of the region in the context of its positioning.

Research results. The essence of economic security of regions can be defined as a state of regional economy and institutions of power, which provides guaranteed protection of regional interests, independence of the chosen strategic course, social orientation, and sufficient economic potential even under adverse conditions of internal and external processes. The positioning of economic security of the regions is determined based on certain principles that create a political and legal basis for the protection of regional economic interests in conjunction with the national interests of the country.

The key risks to the economic security of the regions of Ukraine should be considered:

- critical inhibition of Ukraine's economic development and deterioration of key macroeconomic indicators (macroeconomic imbalance in key indicators);

- curtailment of industrial production in the region;

- reduction of economic activity, primarily investment;

- deterioration of the welfare of the population (households) and rising unemployment;

- increase of debt pressure, primarily in the public sector;

- increase of the shadowing of economic activities [1, p. 144].

Thus, the positioning of the regions due to its economic security is enhanced by certain criteria-indexes-indicators. The most important of them are: the structure of gross regional product (GRP), the volume and pace of industrial development, the volume and dynamics of investment; natural resource production and scientific and technical potential; resource efficiency; competitiveness of the region's economy; unemployment rate; quality of life, degree of income differentiation, provision of the population with material goods and services; energy dependence; integration into the national economy, etc.

The economic security of the state directly depends on the economic security of the regions and vice versa. The main problem of economic security has an important aspect-ensuring effective management of regional policy. Within the framework of the new regional policy, the regions are given the right to independently decide on the development and use of natural resources, development of economic sectors, market infrastructure, etc. Based on the fact that these problems have significant differences and, accordingly, peculiar forms of manifestation in different regions of the country, i.e. different positions about the national economy [2, p. 98]. 
Building an effective system of positioning the region is quite a difficult task in terms of its practical implementation, as it involves the comprehensive integration of various management subsystems and their holistic focus on security priorities. The implementation of this task should also be considered as a strategically important prerequisite for positioning in the context of economic development of the region. At the same time, the uncertainty of the external environment requires taking into account a whole range of factors in the process of managing the economic security of the region, which directly or indirectly determine it. Building a positioning system for the region should take into account the potential for development as a whole. And increasing the level of economic security of the region depends on the degree of state support and development of state programs of regional development, as well as on the placement of government orders for the supply of products for the needs of the whole country [3, p. 72].

Thus, the positioning of the region and the context of its economic security is a complex set of elements that implements the basic principles and functions of governance, able to ensure an acceptable state of economic security, has the properties to adapt and continuous improvement to changes in internal and external environment.

Assessment of the positioning of the region and the context of its economic security can be carried out in the following main areas:

- level of poverty and unemployment in the region;

Table 1. Characteristics of modern positioning of some security sectors and the consequences of such positioning [5, p. 67-72]

\begin{tabular}{|c|c|c|}
\hline Security sector & $\begin{array}{c}\text { Characteristics } \\
\text { of modern positioning }\end{array}$ & $\begin{array}{l}\text { Consequences } \\
\text { of such positioning }\end{array}$ \\
\hline \multirow[t]{2}{*}{$\begin{array}{l}\text { Economic } \\
\text { sector }\end{array}$} & $\begin{array}{l}\text { Low level of use of technologies, outdated } \\
\text { production equipment in the structure mate- } \\
\text { rial and technical equipment of enterprises; } \\
\text { low level of renewal of fixed assets }\end{array}$ & $\begin{array}{l}\text { Low competitiveness of products of enterprises in } \\
\text { the region; non-compliance of products and services } \\
\text { with standards }\end{array}$ \\
\hline & $\begin{array}{l}\text { Reduction of fixed assets; low profitability of } \\
\text { regional producers; termination of financial } \\
\text { and economic activities of enterprises }\end{array}$ & $\begin{array}{l}\text { Rising unemployment; inflated cost of products of } \\
\text { regional manufacturers due to the high cost of dep- } \\
\text { reciation of equipment; forced reduction of regional } \\
\text { product production }\end{array}$ \\
\hline Social sector & $\begin{array}{l}\text { Changing the level, structure of income and } \\
\text { expenditure of the population; sharp differen- } \\
\text { tiation of the population by income, standard } \\
\text { and quality of life; increasing poverty; chang- } \\
\text { ing demographic situation }\end{array}$ & $\begin{array}{l}\text { Increasing the number of socially vulnerable groups } \\
\text { of the urban population compared to rural popula- } \\
\text { tion; criminalization of society; migration; social } \\
\text { growth tension }\end{array}$ \\
\hline $\begin{array}{l}\text { Social political } \\
\text { sector }\end{array}$ & $\begin{array}{l}\text { Interethnic, interfaith and interethnic tensions, } \\
\text { political instability }\end{array}$ & $\begin{array}{l}\text { The possibility of developing regional separatism } \\
\text { and the collapse of the state }\end{array}$ \\
\hline Financial sector & $\begin{array}{l}\text { Reducing the efficiency of the regional ta- } \\
\text { xation system; irrational distribution of ex- } \\
\text { penditures in the structure of the regional } \\
\text { budget }\end{array}$ & $\begin{array}{l}\text { Low level of budget revenues in the region; growing } \\
\text { trends of divergence in the development of regions; } \\
\text { the presence of depressed, backward areas; the gap } \\
\text { in the production of national income per capita by } \\
\text { region }\end{array}$ \\
\hline \multirow{4}{*}{$\begin{array}{l}\text { Institutional } \\
\text { administrative } \\
\text { sector } \\
\text { Externally-eco- } \\
\text { nomic and cur- } \\
\text { rency financial } \\
\text { sector }\end{array}$} & $\begin{array}{l}\text { Weakening of the system of public administra- } \\
\text { tion and control; penetration of crime into } \\
\text { power structure; weakening of the judiciary }\end{array}$ & $\begin{array}{l}\text { Criminalization of economic activity; growing cor- } \\
\text { ruption; deterioration of the investment climate; } \\
\text { rising social tensions }\end{array}$ \\
\hline & Falling competitiveness of regional producers & $\begin{array}{l}\text { Reduction of regional product production, rising } \\
\text { unemployment }\end{array}$ \\
\hline & $\begin{array}{l}\text { Increasing dependence of regional economic } \\
\text { systems on foreign capital, imports of food, } \\
\text { energy and equipment }\end{array}$ & $\begin{array}{l}\text { Orientation of buyers on imported goods, outflow of } \\
\text { foreign currency; producers' need for loans and in- } \\
\text { creasing public external debt }\end{array}$ \\
\hline & $\begin{array}{l}\text { Underfunding of education and science; cur- } \\
\text { tailment of research and development }\end{array}$ & $\begin{array}{l}\text { Disintegration of scientific teams; decrease person- } \\
\text { nel and scientific and technical potential region }\end{array}$ \\
\hline
\end{tabular}




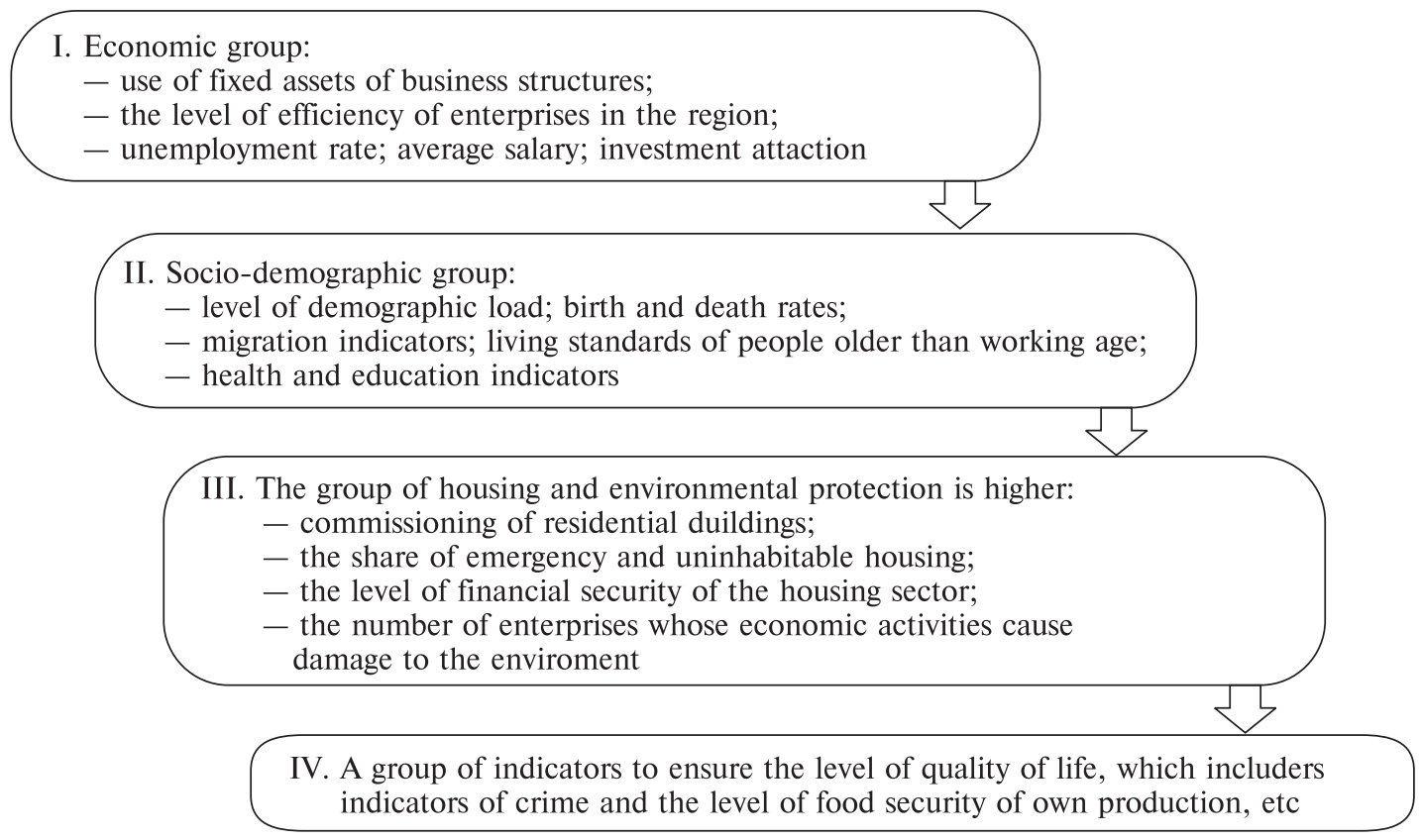

Fig. 1. Methodical approach to assessing the economic security of the region in the context of its positioning [6, p. 36-45].

- quality of life of the population;

- demographic component of socio-economic security of the region;

- ability of the region's economy to sustainable growth;

- stability of the financial system of the region;

- support of the scientific potential of the region;

- dependence of the region's economy on imports of the most important types of products;

- relations of the region with the countries of the European Union [4, p. 227-231].

However, the list of areas of regional positioning is quite large due to the large number of threats to the economic security of the region, so all regional processes that directly or indirectly affect the positioning of the region require in-depth analysis and forecasting of consequences. Table 1 describes the current positioning of some security sectors and the consequences of such positioning.

To be able to identify on time problematic issues that need to be addressed at the state or regional level, a methodological approach to assessing the level of regional economic security in the context of its positioning is proposed. It contains a system of basic indicators that allow to quantify the level of economic security of the region in the context of its positioning, Fig.1.

Appropriate provision of goals should be used to carry out high-quality positioning of the region, eliminate the consequences of economic threats, as each level of goals of economic security of the region includes goals of business, population, government, so the development and detailing of goals should take place within each level in all directions for economic security of the region.

Given the goals that are taken into account when positioning the region, the whole process can be structured into the following blocks:

1) organizational and analytical support (analysis of external and internal threats to the socioeconomic security of the region, development of a system of indicators (indicators) and their threshold values);

2) methodological and information support (creation of a monitoring system: data collection and processing, development of methods of diagnostics and modeling of the level of the socio-economic security system of the region, etc.);

3) conceptual software (development of a comprehensive program for socio-economic security of the region, the necessary measures, concepts, strategies, formation of organizational structures, adoption of institutional changes) [7, p. 89-94].

However, some scholars [13, p. 18-25] insist on the mandatory functioning of the mechanism of economic security of regions in the context of their positioning. In this case, the organizational and managerial mechanism for ensuring the economic security of the region contains the following objects of economic security of the regions are: the real sector of the economy; financial sector, including fiscal and credit-financial spheres, in- 


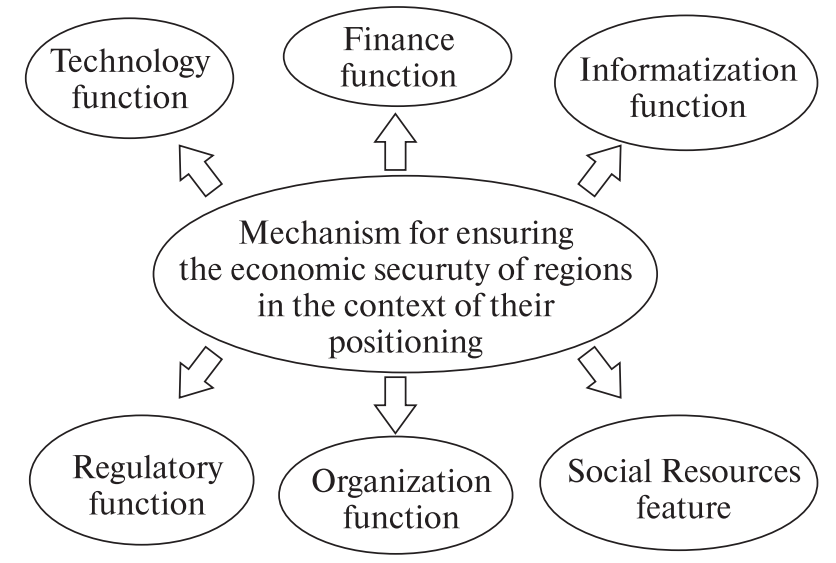

Fig. 2. Functional components of a simple support mechanism economic security of regions in the context of their positioning [9, p. 81-86].

surance, financial markets; foreign trade sector; household sector, consumer markets and trade; institutes of public administration, etc. The subjects of the mechanism for ensuring the economic security of the regions in the context of their positioning are, first of all, the executive and legislative authorities.

The functional components of the mechanism for ensuring the economic security of regions in the context of their positioning are presented in Fig. 2.

The function finance includes: formation of the budget of the region; financing of measures to stabilize critical situations; preferential courts, taxes, subsidies and loans; penalties; insurance system; licensing; certification; assessment of all resources; pricing; regional programs investment programs; taxation; customs regulation; special funds. The informatization function includes: monitoring; audit; control; assessment; generalization and analysis. The technology function includes: development of new technologies; improvement of existing technologies; promotion of advanced technologies. The function of «Regulatory support» includes: development of legislation; revision of norms and standards. The organization function includes: structure, subordination, systematization of economic security bodies of the region; formation of the economic security infrastructure of the region; introduction of advanced management methods. The social resources function includes: development of education and upbringing; cultural development; promotion and advertising of high standards of economic security of the region [10, p. 44-48].
The function finance includes: formation of the budget of the region; financing of measures to stabilize critical situations; preferential courts, taxes, subsidies and loans; penalties; insurance system; licensing; certification; assessment of all resources; pricing; regional programs investment programs; taxation; customs regulation; special funds. The informatization function includes: monitoring; audit; control; assessment; generalization and analysis. The technology function includes: development of new technologies; improvement of existing technologies; promotion of advanced technologies. The function of regulatory support includes: development of legislation; revision of norms and standards. The organization function includes: structure, subordination, systematization of economic security bodies of the region; formation of the economic security infrastructure of the region; introduction of advanced management methods. The social resources function includes: development of education and upbringing; cultural development; promotion and advertising of high standards of economic security of the region [11, p. 135-148].

The effective functioning of the mechanism for ensuring the economic security of regions in the context of their positioning requires the effective functioning of all actors synchronously, and the synergetic effect in a formalized form can be depicted as follows:

$$
\mathrm{S}=(\mathrm{A}, \mathrm{B}, \mathrm{C}, \mathrm{D}, \mathrm{E}, \mathrm{F}) \geq \operatorname{Max} \mathrm{D}
$$

where: $\mathrm{S}$ - synergetic effect of the mechanism of economic security of regions in the context of their positioning; A - a function finance; $\mathrm{B}-$ informatization function; $\mathrm{C}-\mathrm{a}$ function of technology; D - a function of social resources; E regulatory function; $\mathrm{F}-$ a function of the organization; Max D - the maximum sum of functions.

Conclusions. Studies of economic security of the region in the context of its positioning allowed to identify key risks of economic security of Ukraine, the main directions of assessing the positioning of the region and the context of its economic security, characteristics of modern positioning of some security sectors and the consequences of such positioning components of a simple mechanism for ensuring the economic security of regions in the context of their positioning, it allowed to characterize the synergetic effect in a formalized form. This should be calculated in further research. 


\section{REFERENCES}

1. Modeliuvannia ekonomichnoi bezpeky: derzhava, rehion, pidpryiemstvo. Za red. V.M. Heitsia. Kharkiv: INZhEK, 2006. 240 p. [in Ukrainian].

2. Herasymchuk Z.V., Vavdiiuk. N.S. Ekonomichna bezpeka rehionu: diahnostyka ta mekhanizm zabezpechennia. Lutsk: Nadstyria, 2006. 244 p. [in Ukrainian].

3. Gutman G.V., Lapygin Ju.N., Prilepskij A.I. Jekonomicheskaja bezopasnost' regiona: teorija i praktika. Moscow: Nauka, 1996. 116 p. [in Russian].

4. Shurshyn V.O. Osoblyvosti formuvannia systemy ekonomichnoi bezpeky rehionu. Tavriiskyi naukovyi visnyk: zbirnyk nauk. prats KhDAU. 2007. Iss. 55. P. 227-231 [in Ukrainian].

5. Bilyk R.R. Mekhanizmy ta instrumenty zabezpechennia ekonomichnoi bezpeky rehioniv Ukrainy v protsesi detsentralizatsii. Biznes Inform. 2015. No. 9. P. 67-72 [in Ukrainian].

6. Nosova O.V., Makovoz O.S. Modeli ekonomichnoi bezpeky rehionu. Visnyk Natsionalnoi yurydychnoi akademii Ukrainy imeni Yaroslava Mudroho. 2011. No. 4. P. 36-45 [in Ukrainian].

7. Povzun D.I. Ekonomichna bezpeka rehionu yak skladova natsionalnoi bezpeky Ukrainy. Ekonomika ta derzhava. 2020. No. 8. P. 89-94. https://doi.org/10.32702/2306-6806.2020.8.89 [in Ukrainian].

8. Akimova L.M. Stanovlennia systemy ekonomichnoi bezpeky derzhavy v Ukraini: sutnist, rivni, skladnyky. Publichne administruvannia: teoriia ta praktyka. 2018. No. 1 (19). P. 1-11 [in Ukrainian].

9. Hbur Z.V. Ekonomichna bezpeka yak odna zi skladovykh zabezpechennia natsionalnoi bezpeky Ukrainy na suchasnomu etapi. Investytsii: praktyka ta dosvid. 2017. № 18. P. 81-86 [in Ukrainian].

10. Agapova T.N. Metodika i instrumentarij dlja monitoringa jekonomicheskoj bezopasnosti regiona. Voprosy statistiki. 2001. No. 2. P. 44-48 [in Russian].

11. Burbelo O.A., Patriarkh T.V., Burbelo S.O. Ekonomichna bezpeka rehionu v systemi yoho sotsialno-ekonomichnoho rozvytku. Visnyk Luhanskoho derzhavnoho universytetu vnutrishnikh sprav imeni E.O. Didorenka. 2020. No. 1 (89). P. 135-148. https://doi.org/10.33766/2524-0323.89.135-148 [in Ukrainian].

12. Antonenko V.N., Portnova G.A., Burluckij B.V. Konceptual'nyj podhod k issledovaniju jekonomicheskoj bezopasnosti regionov Ukrainy v aspekte sovremennoj integracionnoj paradigmy. Ekonomichna bezpeka $v$ umovakh hlobalizatsii svitovoi ekonomiky. Dnipropetrovsk: FOP Drobiazko S.I., 2014. Vol. 1. P. 344-353 [in Russian].

13. Dykan V.V., Aleksandrova O.Iu., Mekhanizm zabezpechennia ekonomichnoi bezpeky rehionu: sutnist, skladovi, napriamy dii. Visnyk ekonomiky transportu i promyslovosti. 2017. No. 58. P. 18-25 [in Ukrainian].

\section{СПИСОК ЛІТЕРАТУРИ}

Received 10.10.2021

1. Моделювання економічної безпеки: держава, регіон, підприємство. За ред. В.М. Гейця. Харків: ІНЖЕК, 2006. $240 \mathrm{c}$.

2. Герасимчук 3.В., Вавдіюк. Н.С. Економічна безпека регіону: діагностика та механізм забезпечення. Луцьк: Надстир'я, 2006. 244 с.

3. Гутман Г.В., Лапыгин Ю.Н., Прилепский А.И. Экономическая безопасность региона: теория и практика. Москва: Наука, 1996. 116 с.

4. Шуршин В.О. Особливості формування системи економічної безпеки регіону. Таврійський науковий вісник: збірник наук. праць ХДАУ. 2007. Вип. 55. С. 227-231.

5. Білик Р.Р. Механізми та інструменти забезпечення економічної безпеки регіонів України в процесі децентралізації. Бізнес Інформ. 2015. № 9. С. 67-72.

6. Носова О.В., Маковоз О.С. Моделі економічної безпеки регіону. Вісник Національної юридичної академії Украӥни імені Ярослава Мудрого. 2011. № 4. С. 36-45.

7. Повзун Д.І. Економічна безпека регіону як складова національної безпеки України. Економіка та держава. 2020. № 8. C. 89-94. https://doi.org/10.32702/2306-6806.2020.8.89

8. Акімова Л.М. Становлення системи економічної безпеки держави в Україні: сутність, рівні, складники. Публічне адміністрування: теорія та практика. 2018. № 1 (19). С. 1-11.

9. Гбур 3.В. Економічна безпека як одна зі складових забезпечення національної безпеки України на сучасному етапі. Інвестицї: практика та досвід. 2017. № 18. С. 81-86.

10. Агапова Т.Н. Методика и инструментарий для мониторинга экономической безопасности региона. Bonросы статистики. 2001. № 2. С. 44-48.

11. Бурбело О.А., Патріарх Т.В., Бурбело С.О. Економічна безпека регіону в системі його соціально-економічного розвитку. Вісник Луганського держсавного університету внутрішніх справ імені Е.О. Дідоренка. 2020. № 1 (89). C. 135-148. https://doi.org/10.33766/2524-0323.89.135-148

12. Антоненко В.Н., Портнова Г.А., Бурлуцкий Б.В. Концептуальный подход к исследованию экономической безопасности регионов Украины в аспекте современной интеграционной парадигмы. Економічна безпека в умовах глобалізації світової економіки. Дніпропетровськ: ФОП Дробязко С.І., 2014. Т. 1. С. 344-353.

13. Дикань В.В., Александрова О.Ю., Механізм забезпечення економічної безпеки регіону: сутність, складові, напрями дії. Вісник економіки транспорту і промисловості. 2017. № 58. С. 18-25.

Надійшла 10.10.2021 
Д.О. Грицишен

Державний університет «Житомирська політехніка», м. Житомир, Україна, orcid.org/0000-0001-5484-6421

В.О. Кучменко

Державний університет «Житомирська політехніка», м. Житомир, Україна, orcid.org/0000-0001-6018-2406

Д.В. Заблодська

Державна установа «Інститут економіко-правових досліджень

імені В.К. Мамутова НАН України», м. Київ, Україна

orcid.org/0000-0002-5670-597X

\section{ЕКОНОМІЧНА БЕЗПЕКА РЕГІОНУ}

В КОНТЕКСТІ ЙОГО ПОЗИЦІОНУВАННЯ

Подано результати узагальнення наукових підходів до економічної безпеки регіону в контексті його позиціонування. Визначено ключові ризики економічної безпеки регіонів України, найважливіші критерії позиціонування регіонів: структура валового регіонального продукту, обсяг і темпи розвитку промисловості, обсяг i динаміка інвестицій; природно-ресурсний виробничий і науково-технічний потенціал; ефективність використання ресурсів; конкурентоспроможність економіки регіону; рівень безробіття; якість життя, ступінь диференціації доходів, забезпеченість населення матеріальними благами й послугами; енергетична залежність; інтегрованість у національну економіку тощо.

Зазначено, що головна проблема економічної безпеки - забезпечення ефективного управління регіональною політикою, а оцінка позиціонування регіону, в контексті його економічної безпеки, може бути здійснена в основних напрямах: рівень бідності й безробіття в регіоні, якість життя населення, демографічна складова соціально-економічної безпеки регіону, здатність економіки регіону до стійкого росту, стійкість фінансової системи регіону, підтримка наукового потенціалу регіону, залежність економіки регіону від імпорту найважливіших видів продукції, взаємини регіону з країнами Європейського Союзу.

Надано характеристику сучасному позиціонуванню деяких секторів безпеки та наслідки такого позиціонування. Сформовано систему основних індикаторів, які дають можливість кількісно визначити рівень економічної безпеки регіону. Висвітлено методичний підхід до оцінювання економічної безпеки регіону в контексті його позиціонування. Зазначено, що процес позиціонування регіонів може бути структуровано у такі блоки: організаційно-аналітичне забезпечення, методичне та інформаційне забезпечення, концептуальнопрограмне забезпечення.

Подано функціональні компоненти механізму забезпечення економічної безпеки регіонів в контексті їхнього позиціонування. Доведено, що ефективне функціонування механізму забезпечення економічної безпеки регіонів вимагає ефективного функціонування всіх суб’єктів синхронно, що дало змогу сформулювати синергетичний ефект у формалізованому вигляді.

Ключові слова: економічна безпека регіону, позиціонування, індикатори, напрями, механізм, функціональні компоненти, синергетичний ефект. 